\title{
Greenhouse gas emission effect of suspending slash pile burning in Ontario's managed forests
}

\author{
by Michael T. Ter-Mikaelian 1,", Stephen J. Colombo ${ }^{1}$, and Jiaxin Chen ${ }^{1}$
}

\begin{abstract}
Ontario has made a commitment to reduce its greenhouse gas (GHG) emissions by 15, 37, and $80 \%$ below 1990 levels by 2020 , 2030, and 2050, respectively. Ontario's forest managers can contribute to meeting these targets by implementing changes to forestry practices that either reduce emissions from operations or increase carbon sequestration in forest ecosystems and harvested wood products. We present an analysis of the effects on GHG emissions resulting from suspending the current management practice of slash pile burning (burning harvest residue in the forest without energy recovery). The analysis was performed for each of Ontario's forest management units (FMU) with assumed suspension of slash pile burning for four different periods: 2016-2025, 2016-2050, 2016-2075, and 2016-2100. Annual and cumulative avoided emissions from suspending slash pile burning that would have occurred with current practices were estimated from planned harvest volume and area adjusted to reflect harvesting levels from 1990 to 2009, data on slash pile burning from 2008 to 2013, and emission factors for combustion and decay of wood estimated from the literature. Suspending slash pile burning was estimated to reduce GHG emissions by year 2100 in all four no-burn scenarios, with cumulative GHG emission reductions estimated at $-0.7,-4.5,-14.1$, and $-33.4 \mathrm{Mt} \mathrm{CO}_{2}$ eq (million tonnes of $\mathrm{CO}_{2}$ equivalent), respectively. At the same time, suspending slash pile burning for the above-listed four periods resulted in losses of forest area by 2100 estimated at 7200, 24000, 40800, and 57800, respectively. The accuracy of these projections is affected by uncertainty in estimates of several components of the analysis, of which the primary one is the historical rate of slash pile burning. Improvement in measuring and reporting procedures is needed to obtain more reliable estimates of the amount of slash burned.
\end{abstract}

Keywords: forest management, harvest residue, decay, avoided emissions

\section{RÉSUMÉ}

L'Ontario sest engagée engagé à réduire ses émissions de gaz à effet de serre (GES) de 15, 37 et $80 \%$ en dessous des niveaux de 1990 d'ici respectivement 2020, 2030 et 2050 respectivement. Les aménagistes forestiers des forêts de l'Ontario peuvent contribuer à l'atteinte de ces objectifs en modifiant lesimplantant des modifications aux pratiques forestières qui peuvent soitpour réduire les émissions au moment de la récolte, soit ou accroitre la séquestration du carbone dans les écosystèmes forestiers et les produits ligneux du bois récoltés. Nous présentons une analyse des effets que pourrait amener linterruption du brûlage des empilements de résidus (brûlage des résidus de bois sans récupération énergétique) des sur les émissions de GES découlant de la suspension de la pratique courante d’aménagement qui consiste à brûler les empilements de résidus (brûlage des résidus de bois sans récupération énergétique). Cette analyse a été effectuée pour chacune des unités d’aménagement forestier de l'Ontario en présumant la suspension du brûlage des empilements de résidus au cours desur quatre périodes différentes : 2016-2025, 2016-2050, 2016-2075, et 2016-2100. Les émissions annuelles et cumulatives évitées par la suspension du brûlage des résidus qui seraient survenues selon les pratiques courantes, ont été estimées à partir du volume prévu de récolte et de la superficie associée et ajustées pour refléter les niveaux de récolte entre 1990 et 2009, des données sur les empilements de débris résidus de 2008 à 2013, et des facteurs affectant lesd' émissions liées à la combustion et à la dégradation du bois selon les estimations retrouvées dans la littératuredocumentation. On estime que suspendre le La suspension du brûlage des résidus de bois a été estimée équivaloirréduirait 1 à une réduction des émissions de GES d'ici 2100, dans les quatre scénarios sans brûlage respectivement de, comportant des réductions cumulatives démissions de GES respectivement de - $0,7,-4,5,-14,1$ et $-33,4$ Mt d’équivalent déquivalent $\mathrm{CO}_{2}$ (millions de tonnes déquivalent $\mathrm{CO}_{2}$ ). Du coup, la suspension du brûlage des débrisrésidus pour les périodes mentionnées ci-dessus se serait traduite par a entraîné une réduction de la superficie forestière estimée en 2100 estimée de,à respectivement, $7200,24000,40800$ et 57800 . La précision de ces projections dépend est tributaire de l'incertitude entourant liée à l’estimation les estimations de certains éléments de l'analyse, dont en premier lieu notamment en premier lieu les taux historiques de brûlage des empilements de résidus. Il faudrait améliorer les Une amélioration des procédures de mesurage et de notification reddition des comptes est requise afinpour dobtenir des estimations fiables de sur la quantité de débris résidus brûlés.

Mots clés : aménagement forestier, résidus de récolte, dégradation, émissions évitées

${ }^{1}$ Ontario Ministry of Natural Resources and Forestry, Ontario Forest Research Institute, 1235 Queen St. East, Sault Ste. Marie, Ontario P6A 2E5; "Corresponding author's e-mail: michael.termikaelian@ontario.ca 


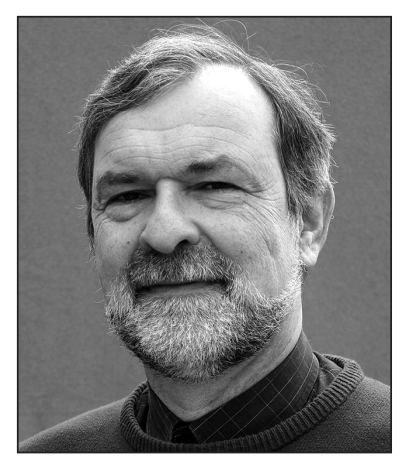

Michael T. Ter-Mikaelian

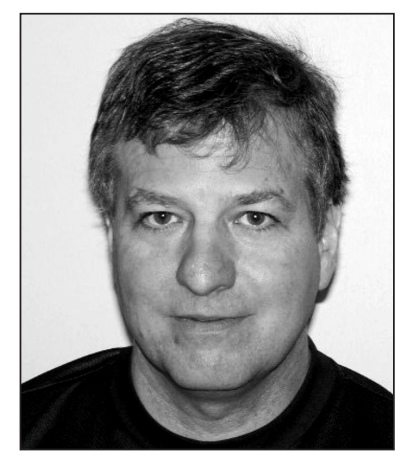

Stephen J. Colombo

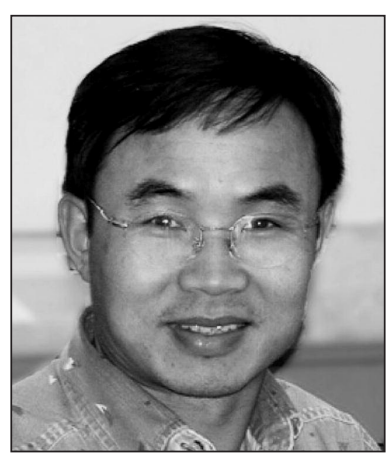

Jiaxin Chen human-induced) from forests and forestry practices. Examples of such opportunities include increasing protection from forest fires and insect outbreaks, harvesting stands at higher average ages, and reducing haul distances from harvest sites to processing facilities, with reductions in GHG emissions achievable within a few years of implementing changes. Long-term involve forest management practices that increase carbon removals

\section{Introduction}

In 2015, the government of Ontario announced its commitment to reduce provincial greenhouse gas (GHG) emissions by $37 \%$ below 1990 levels by 2030 . This target was set in addition to previously announced goals of reducing provincial GHG emissions by $15 \%$ below 1990 levels by 2020 and by $80 \%$ by $2050 .^{2}$ By making these commitments, Ontario has joined other subnational jurisdictions (e.g., British Columbia; California) that have set GHG emission reduction targets. Meeting Ontario's targets will require a range of initiatives throughout various sectors of the economy, such as shifting to public transportation, using fuels with better environmental performance, developing clean technologies, increasing heat efficiency of buildings, and many others (OMOECC 2014).

Forestry plays a unique role in climate change mitigation by being one of the few sectors of the economy, along with agriculture, that both generates emissions and removes carbon from the atmosphere; the carbon removed by forests is stored in vegetation, soil, and harvested wood products. In fact, over the $20^{\text {th }}$ century, net removal of carbon from the atmosphere by Canada's managed forests, including carbon stored in harvested wood products, exceeded carbon emitted by all fossil fuels burned in Canada over the same period (Chen et al. 2014). The importance of forests for mitigating climate change was recognized by the Intergovernmental Panel on Climate Change in a statement that sustainable forest management aimed at maintaining forest carbon stocks, while producing a steady flow of fibre or energy, would provide the largest sustained long-term mitigation benefit (IPCC 2007). In Ontario, sustainable forest management is mandated by the Crown Forest Sustainability Act (Statutes of Ontario 1995) and, by the end of the $21^{\text {st }}$ century, Ontario's managed forests are projected to increase carbon storage in forests and harvested wood products by over 330 million tonnes of carbon (Ter-Mikaelian et al. 2013).

Increasing the contribution of Ontario's managed forests to climate change mitigation requires an evaluation of forest management activities that may be available within the context of sustainable forest management. Near-term opportunities involve changes that reduce GHG emissions (both natural and

${ }^{2}$ http://news.ontario.ca/ene/en/2015/05/ontario-first-province-incanada-to-set-2030-greenhouse-gas-pollution-reduction-target .html [accessed 2 February 2016]. from the atmosphere by increasing carbon sequestration and storage in the combined stocks of forests and wood products. Examples include more immediate regeneration and planting of faster growing tree species; such changes to management practices would take several decades to substantially affect the overall balance of GHG emissions and removals.

One of the near-term opportunities is suspending the current practice of burning slash piles. Here slash refers to the residue from harvesting operations and includes unmerchantable aboveground parts of trees (tops and limbs). It may also include small trees and unmerchantable and decayed wood but does not include stumps and roots. A current recommended management practice is to gather slash in piles and dispose of it by controlled burning (SFI 2009, OMNR 2010). Slash pile burning emits GHGs to the atmosphere from combustion but prevents the loss of productive land available for forest regeneration under the slash piles, which decompose slowly over decades reducing potential carbon sequestration by re-growing forests on that land. The objective of this study was to assess the effect of suspending slash pile burning in Ontario's managed forests on GHG emissions.

\section{Methods and Materials}

The study area was Ontario's Crown (i.e., publicly owned) forests managed for wood fibre. The respective area known as the Area of Undertaking (AOU) is located in a province-wide $\mathrm{N}$ (the area that bounds the polygons in Fig. 1) that includes hardwood-dominated stands in the Great Lakes-St. Lawrence forest region and conifer-dominated stands in the boreal forest region. The most prevalent forest types are: (a) conifer upland ( 7.7 million ha), dominated by black spruce (Picea mariana (Mill.) B.S.P.), white spruce (Picea glauca (Moench) Voss), jack pine (Pinus banksiana Lamb.), and balsam fir (Abies balsamea (L.) Mill.) occurring on upland or well drained to shallow sites; (b) conifer lowland (7.1 million ha), dominated by black spruce, often associated with white cedar (Thuja occidentalis L.) and larch (Larix laricina (Du Roi) K. Koch), commonly found on moist to wet or organic soils on lowland sites; and, (c) mixedwood (6.1 million ha), occurring throughout the boreal and boreal transitional forest and composed mostly of black and white spruce, trembling aspen (Populus tremuloides Michx.), jack pine, balsam fir, and white birch (Betula papyrifera Marsh.). More detail about Ontario's climate, geography, and tree species distribution is provided by Watkins (2011). band within north-south limits of approximately $51^{\circ}$ and $45^{\circ}$ 
For management purposes, forest that can be harvested within the AOU is divided into 41 (as of 2015) forest management units (FMU) covering a total forest area of 28.3 million ha (polygons in Fig. 1). Within these managed forest areas, over 4.7 million ha $(16.5 \%)$ of the total forest area is protected from harvesting (e.g., small parks and other reserves). Forest companies manage FMUs following regulations set by the Ontario Ministry of Natural Resources and Forestry that aim to ensure forest sustainability. Forestry activities within each FMU are governed by an approved forest management plan that is updated on a five-year cycle. Reports on completed forest operations are submitted annually and are available for public downloading for the period 2008-2013. ${ }^{3}$

To assess changes in GHG emissions resulting from suspending slash pile burning requires consideration of two scenarios:

- A baseline scenario (also referred to as business-as-usual) constitutes continuation of the current management practice of slash pile burning. We assumed that harvesting and slash pile burning in each FMU occurred at historical levels for harvest volume and amount of slash burned per year, respectively, and resulted in emissions of carbon dioxide $\left(\mathrm{CO}_{2}\right)$, carbon monoxide (CO), methane $\left(\mathrm{CH}_{4}\right)$, and nitrous oxide $\left(\mathrm{N}_{2} 0\right)$. Reporting emissions of these gases is required by international standards for reporting GHG emissions from wildfires and controlled burning (IPCC 2003, Environment Canada 2015).

- The no-burn scenario refers to suspending slash pile burning in managed Crown forests within the AOU. When unburned, slash from whole tree harvesting is left alongside forest access roads in piles of "half-section of sphere" or "half-ellipsoid" shape (referred to as beehive and windrow, respectively) and with widths ranging from 8 to $16 \mathrm{~m}$ (Gautam et al. 2012) where it decays, emitting $\mathrm{CO}_{2}$; emissions of other GHGs are negligible. For this study, suspension of slash pile burning was considered for four time periods:

2016-2025 (with slash pile burning resuming in 2026)

2016-2050 (with slash pile burning resuming in 2051)

2016-2075 (with slash pile burning resuming in 2076)

2016-2100.

The inclusion of four different periods was to accommodate considerations (e.g., loss of productive forest land) that might affect the feasibility of permanently suspending slash pile burning.

3 http://www.efmp.lrc.gov.on.ca/eFMP/home.do?currentFmu=\& language $=$ en [accessed 2 February 2016].

\section{Analytical methods}

Methods of assessing the differences in GHG emissions between the no-burn and baseline scenarios do not depend on the period for which slash pile burning is suspended. Therefore, analytical methods refer simply to the no-burn scenario and the period is specified when reporting results (e.g., no-burn 2016-2025). The GHG emissions for both noburn and baseline scenarios were estimated for each FMU within the AOU. The difference in GHG emissions (in $\mathrm{t}$ $\mathrm{CO}_{2}$ eq: tonnes of $\mathrm{CO}_{2}$ equivalents) between no-burn and baseline scenarios for an individual FMU was estimated using the equation:

(1) $\mathrm{E}_{\text {diff }}(\mathrm{t})=\left[\mathrm{E}_{\text {no-burn }}(\mathrm{t})-\mathrm{R}_{\text {no-burn }}(\mathrm{t})\right]-\left[\mathrm{E}_{\text {base }}(\mathrm{t})-\mathrm{R}_{\text {base }}(\mathrm{t})\right]$,

Where:

$\mathrm{E}_{\text {diff }}$ is the difference in annual GHG emissions between the no-burn and baseline scenarios in year t;

$\mathrm{E}_{\text {no-burn }}$ are GHG emissions from the decay of slash piles in the no-burn scenario in year $t$;

$\mathrm{R}_{\text {no-burn }}$ are removals of $\mathrm{CO}_{2}$ from the atmosphere in year 
t by regenerating forest in areas cleared of slash piles due to their decay in the no-burn scenario;

$\mathrm{E}_{\text {base }}$ is the total amount of GHG emissions in year $\mathrm{t}$ from burning slash piles in the baseline scenario;

$\mathrm{R}_{\text {base }}$ are removals of $\mathrm{CO}_{2}$ from the atmosphere in year $\mathrm{t}$ by regenerating forest in areas cleared by slash pile burning in the baseline scenario t; and,

$t$ is the year for which emissions and removals are estimated; for simplicity $\mathrm{t}$ is omitted from the following equations except where it affects clarity.

Equation (1) was used to estimate GHG emissions and removals only for the fraction of slash (and the area covered with it) that would be burned in the baseline scenario; the fate of the fraction of slash not burned in the baseline scenario is identical in both scenarios and therefore respective emissions and removals are not included. The amount of slash pile dry matter burned in the baseline scenario in a given FMU in a given year was estimated by:

(2) $\mathrm{B}_{\mathrm{sp}}=\mathrm{V}_{\mathrm{sp}} \cdot \mathrm{F}_{\mathrm{sp}} \cdot \mathrm{S}_{\mathrm{sp}} \cdot \mathrm{R} \cdot \mathrm{Q}$,

Where:

$B$ is the mass of slash pile matter (oven-dry tonnes, odt) burned in the baseline scenario (i.e., "burnable" slash);

$\mathrm{V}$ is the planned harvestable merchantable volume $\left(\mathrm{m}^{3}\right)$;

$\mathrm{F}$ is the historical ratio of actual to planned harvestable merchantable volume $\left(\mathrm{m}^{3} \cdot \mathrm{m}^{-3}\right)$;

$\mathrm{S}$ is the mass of slash (odt. $\left.\mathrm{m}^{-3}\right)$ in piles generated per $\mathrm{m}^{3}$ of harvested merchantable volume;

$\mathrm{R}$ is the historical slash pile burning rate (odt burned.odt 1 in all newly generated slash piles), i.e., the fraction of burned slash piles;

$\mathrm{Q}$ is the combustion rate (odt.odt ${ }^{-1}$ ), i.e., the fraction of burned dry matter in an individual burned slash pile; and,

$\mathrm{sp}$ is the species group (con for conifers and $h w d$ for hardwoods).

The amount of GHG emissions produced by burning slash piles in the baseline scenario, $\mathrm{E}_{\mathrm{base}}$, in a given FMU in a given year was calculated by:

(3) $\mathrm{E}_{\text {base }}=\left(\mathrm{B}_{\text {con }}+\mathrm{B}_{\mathrm{Hwd}}\right) \cdot\left(1-\mathrm{C}_{\mathrm{b}}\right) \cdot\left(\mathrm{E}_{\mathrm{CO} 2}+\mathrm{E}_{\mathrm{CO}} \cdot \mathrm{GWP}_{\mathrm{CO}}+\right.$ $\left.\mathrm{E}_{\mathrm{CH} 4} \cdot \mathrm{GWP}_{\mathrm{CH} 4}+\mathrm{E}_{\mathrm{N} 2 \mathrm{O}} \cdot \mathrm{GWP}_{\mathrm{N} 20}\right)$,

Where:

$\mathrm{B}$ is the mass of slash pile matter (odt) burned in the baseline scenario (subscript indicates the species group from which slash was produced);

$\mathrm{C}_{\mathrm{b}}$ is the fraction of combusted dry matter in slash piles converted into black carbon (odt.odt ${ }^{-1}$ );

$\mathrm{E}_{\mathrm{CO} 2}, \mathrm{E}_{\mathrm{CO}}, \mathrm{E}_{\mathrm{CH} 4}$, and $\mathrm{E}_{\mathrm{N} 2 \mathrm{O}}$ are the amounts (t.odt ${ }^{-1}$ ) of $\mathrm{CO}_{2}, \mathrm{CO}, \mathrm{CH}_{4}$, and $\mathrm{N}_{2} \mathrm{O}$, respectively, emitted during combustion of one unit of dry matter in slash piles; and,

$\mathrm{GWP}_{\mathrm{CO}}, \mathrm{GWP}_{\mathrm{CH} 4}$, and $\mathrm{GWP}_{\mathrm{N} 20}$ are global warming potential (GWP) of $\mathrm{CO}, \mathrm{CH}_{4}$, and $\mathrm{N}_{2} \mathrm{O}$, respectively.

In the no-burn scenario, the mass of slash in piles was modelled using the following equation, in which the first term describes the decay of unburned slash piles accumulated by year $\mathrm{t}$ using a negative exponential function and the second term captures the unburned slash piles added in year $\mathrm{t}$ :

(4) $\mathrm{AB}_{\mathrm{sp}}(\mathrm{t})=\mathrm{AB}_{\mathrm{sp}}(\mathrm{t}-1) \cdot \exp \left(-\mathrm{K}_{\mathrm{sp}}\right)+\mathrm{B}_{\mathrm{sp}}(\mathrm{t})$,
Where:

$\mathrm{AB}_{\mathrm{sp}}(\mathrm{t})$ is the accumulated mass (odt) in unburned slash piles at the end of year $t$; and,

$\mathrm{K}_{\mathrm{sp}}$ is the species group-specific decay rate $\left(\right.$ year $^{-1}$ ), i.e., $\mathrm{K}_{\text {con }}$ and $\mathrm{K}_{\text {hwd }}$ in Equation (5) for conifer and hardwood species group, respectively.

GHG emissions from the decay of slash piles in the no-

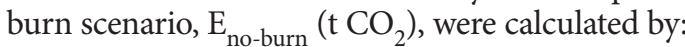

(5) $\mathrm{E}_{\text {no-burn }}=[0.5 \cdot(44 / 12)] \cdot\left\{\mathrm{AB}_{\text {con }}(\mathrm{t}-1) \cdot\left[1-\exp \left(-\mathrm{K}_{\mathrm{con}}\right)\right]+\right.$ $\left.\mathrm{AB}_{\mathrm{hwd}}(\mathrm{t}-1) \cdot\left[1-\exp \left(-\mathrm{K}_{\mathrm{hwd}}\right)\right]\right\}$,

Where multipliers 0.5 and (44/12) convert the decayed fraction of dry matter in slash piles into mass of carbon and $\mathrm{CO}_{2}$, respectively. Note that equation (5) assumes that all decayed dry matter is emitted as $\mathrm{CO}_{2}$.

Area cleared by slash pile burning in the baseline scenario in a given FMU in a given year was estimated using the equation:

(6) $\mathrm{A}=\mathrm{AHA} \cdot\left[\left(\mathrm{V}_{\mathrm{con}} \cdot \mathrm{F}_{\mathrm{con}}+\mathrm{V}_{\mathrm{hwd}} \cdot \mathrm{F}_{\mathrm{hwd}}\right) /\left(\mathrm{V}_{\text {con }}+\mathrm{V}_{\mathrm{hwd}}\right)\right] \cdot \mathrm{U} \cdot \mathrm{R}$

Where:

A is the area (ha) covered with slash piles produced from harvesting in that year; AHA is the available harvest area (ha), i.e., maximum area available for harvesting in that year; $U$ is the fraction of harvest area covered with slash piles (ha.ha ${ }^{-1}$ ); and V, F, and R are as defined in Equation (2). Equation (6) scales down the maximum available harvest area (AHA) to the actual harvest area using the volume-weighted ratio of actual-to-planned harvest volume (the term in square brackets). In this study we assumed that area covered with slash piles in the no-burn scenario was taken out of the productive land for the duration of the simulation period (i.e., $\mathrm{R}_{\text {no-burn }}(\mathrm{t})$ for all $t \leq 2100$ ). This assumption was dictated by uncertainty in the time required for a slash pile to reach the decay level at which the area it covers becomes available for regeneration. The effects of this assumption on total area covered with slash piles and $\mathrm{CO}_{2}$ removals in the no-burn scenario were assessed using the sensitivity analysis described below. Hereafter, productive land refers to areas that can support tree growth but may or may not support the harvesting of timber on a sustained yield basis (OMNRF 2009). The latter definition is sufficiently broad to include all forest types, not just those with commercially viable merchantable volume.

\section{Projected harvest and slash pile production rates}

Future amounts of slash and area of slash piles depended on the projected harvest volumes $(\mathrm{V})$ that, along with projected harvest area (AHA), were obtained from the most recent forest management plans for each FMU. However, projected harvest volumes and areas included in forest management plans represented maximum harvest (which is less than the maximum sustained yield harvesting rate) that can be achieved while meeting all non-timber objectives. The maximum is rarely harvested due to, for example, low market demand and inaccessibility of timber. Therefore, projected harvest volumes and areas were scaled down using historical average ratios of actual-to-planned harvest volumes ( $\mathrm{F}$ in Eqs. 2 and 6). Data on planned and actual harvest volumes for 1990 to 2014 summarized by five-year periods (1990-94, 
1995-99, 2000-04, 2005-09, and 2010-14) were obtained from ARWoods (OMNRF 2015). Since both actual and planned harvest volume fluctuated over time, the following procedure was applied to select a period over which the historical average ratio of actual-to-planned harvest volume was estimated. The ratio of total actual to planned harvest volume was calculated for all combinations of consecutive five-year periods (i.e., 1990-94, 1990-99, 1990-2004, 1990-2009, 1990-2014, 1995-99, 1995-2004, etc.). Calculated ratios were arranged in ascending order and the period 1990-2009 corresponding to the median ratio was selected as the period for which actual-to-planned harvest ratios were estimated separately for conifers and hardwoods for each individual FMU.

Estimates of the mass of slash in piles generated per $\mathrm{m}^{3}$ of harvested merchantable volume (S in Eq. 2) were taken from a study on potential biomass supply for energy generation (Ter-Mikaelian et al. 2015a). The estimates assumed netdown factors between 20 and 30\%, i.e., the fraction of slash left scattered on a harvested site (for ecological purposes and due to harvesting methods), and equalled $0.1761 \mathrm{odt} \cdot \mathrm{m}^{-3}$ and $0.1944 \mathrm{odt} \cdot \mathrm{m}^{-3}$ slash generated by harvesting softwood and hardwood species, respectively.

The slash pile burning rate ( $\mathrm{R}$ in equations 2 and 6 ) is the average fraction of slash piles burned relative to the total number of slash piles generated in a given year. The estimated slash pile burning rates, $\mathrm{R}$, are further multiplied by a slash pile combustion rate constant ( $Q$ in Eq. 2). These rates ( $R$ and Q) were estimated for individual FMUs using information in annual reports on forest operations for 2008 to 2013. If slash pile burning was conducted in a given year, the annual forest operations report for the year included the post burn report that specified gross area of cut blocks, net area of slash coverage, area recovered by burning slash piles, and pile reduction (\% of piles reduced by burning). Then the slash pile burning rate $\mathrm{R}$ was estimated as the ratio of area recovered by slash pile burning to the net area of slash coverage (assuming that all piles were approximately the same size), while the reduction of pile area provides the estimate of slash pile combustion rate, Q. Finally, the fraction of harvested area covered with slash piles (U in Eq. 6) was assumed to be 0.025 , the value used in most annual reports to estimate the net area of slash coverage.

\section{Slash pile burning rate and resulting emissions}

Slash pile burning produces black carbon, which is a product of incomplete combustion and includes char, ash, and charcoal that resists further biological or chemical degradation (Forbes et al. 2006). Although the black carbon pool is relatively small compared to other forest carbon pools, its stability makes it an important component of total forest carbon. Finkral et al. (2012) estimated the fraction of black carbon produced by slash pile burning to be between $1.2 \%$ and $5.1 \%$ of the amount of carbon in the initial pile. These estimates are similar to those of black carbon produced by forest wildfires. According to reviews by Forbes et al. (2006) and Preston and Schmidt (2006), the fraction of black carbon produced in wildfires in boreal forests ranges from $1.5 \%$ to $3.0 \%$ of total carbon combusted. The mid-point of this range $(2.25 \%$, black carbon produced as a fraction of carbon combusted) was used for $\mathrm{C}_{\mathrm{b}}$ (Eq. 3) to estimate the amount of black carbon produced during slash pile burning.
Estimates of gaseous emissions from slash pile combustion were taken from IPCC (2003). Emission factors presented in Table 1 are not specific to slash pile burning but represent emissions during wildfires in boreal forests. Table 1 also includes global warming potential (GWP) factors calculated over 100 years from IPCC (2013).

Table 1. Emission and global warming potential factors for greenhouse gases included in this study; $\mathrm{CO}_{2}$ - carbon dioxide, $\mathrm{CO}$ - carbon monoxide, $\mathrm{CH}_{4}$ - methane, $\mathrm{N}_{2} \mathrm{O}$ - nitrous oxide.

\begin{tabular}{|c|c|c|c|c|}
\hline Greenhouse gas & $\mathrm{CO}_{2}$ & $\mathrm{CO}$ & $\mathrm{CH}_{4}$ & $\mathrm{~N}_{2} \mathrm{O}$ \\
\hline Emission factor, E (tonnes.odt ${ }^{-1}$ ) & 1.55550 & 0.12100 & 0.00805 & 0.00011 \\
\hline Global warming potential, GWP & 1 & 1.692 & 34 & 298 \\
\hline
\end{tabular}

\section{Slash pile decomposition}

Decay of the unburned fraction of slash piles was simulated using a negative exponential function. Decay rates were taken from literature on down wood decomposition because of the lack of information on decomposition of wood in slash piles. Table 2 includes estimates of decay rates from studies on decomposition of down wood conducted in central and eastern Canada and in the upper Great Lakes, USA. Variation in estimates can be attributed to differences in site conditions and wood quality that determine decay rates in the field and methods used to estimate the amount of down wood and its decay rate. Since the estimates in Table 2 come from studies on decomposition of down wood in physical contact with the ground (not on piled slash), we selected values closer to the lower end of reported ranges of estimates to reflect the drier average condition of slash in piles compared to those of down wood spread across forest sites, because dryness impedes decay (Wang et al. 2002, Laiho and Prescott 2004). Hence, we used decay rates of 0.0171 year $^{-1}$ and 0.0365 year $^{-1}$ for softwoods and hardwoods, respectively, corresponding to the 25 th percentiles of the decay rate range for down wood reported in the literature (Table 2 ). The selected decay rates resulted in $50 \%$ loss of pile mass by years 41 and 19 for softwood and hardwood slash, respectively; by year 100 the respective losses of slash pile mass are $82 \%$ and $97 \%$.

\section{Carbon stocks in regenerating forest}

Carbon stocks accumulated in forests regenerating after harvesting were estimated following algorithms and parameter values used in FORCARB-ON (Chen et al. 2010). FORCARB-ON is a large-scale forest carbon budget model developed to project carbon stocks in forests and harvested wood products under various management scenarios. The model is used to estimate forest ecosystem carbon stocks in six pools: live trees (above- and belowground), standing dead trees (above- and belowground), down dead wood (logs and branches $\geq 76 \mathrm{~mm}$ diameter as well as stumps), understory vegetation, forest floor (dead organic matter above the mineral soil horizon including branches and logs $<76 \mathrm{~mm}$ diameter, litter, and humus), and soil.

The main predictors of carbon densities in various pools are merchantable volume or forest age by species group. 
Table 2. Decay rate $\left[K\right.$, year $^{-1}$ ] of down wood in forests of Canada and the Upper Great Lakes

\begin{tabular}{|c|c|c|c|c|}
\hline Common name & Scientific name & $\mathbf{K}$ & Location & Source \\
\hline \multicolumn{5}{|l|}{ Softwoods } \\
\hline Black spruce & Picea mariana (Mill.) BSP & $\begin{array}{l}0.0210 \\
0.0600 \\
0.0500\end{array}$ & $\begin{array}{l}\text { Quebec } \\
\text { Manitoba } \\
\text { Manitoba }\end{array}$ & $\begin{array}{l}\text { Boulanger and Sirois } 2006 \\
\text { Bond-Lamberty and Gower } 2008 \\
\text { Bond-Lamberty and Gower } 2008\end{array}$ \\
\hline Engelmann spruce & Picea engelmannii Parry ex Engelm. & $\begin{array}{l}0.0054 \\
0.0025\end{array}$ & $\begin{array}{l}\text { Alberta } \\
\text { Alberta }\end{array}$ & $\begin{array}{l}\text { Johnson and Greene } 1991 \\
\text { Johnson and Greene } 1991\end{array}$ \\
\hline Jack pine & Pinus banksiana Lamb. & 0.0420 & Minnesota & Alban and Pastor 1993 \\
\hline Lodgepole pine & Pinus contorta Dougl. ex Loud. & $\begin{array}{l}0.0507 \\
0.0171 \\
0.0299 \\
0.0153 \\
0.0045 \\
0.0035 \\
0.0210 \\
0.0180 \\
0.0720\end{array}$ & $\begin{array}{l}\text { Alberta } \\
\text { Alberta } \\
\text { Alberta } \\
\text { Alberta } \\
\text { Alberta } \\
\text { Alberta } \\
\text { British Columbia } \\
\text { British Columbia } \\
\text { Alberta }\end{array}$ & $\begin{array}{l}\text { Laiho and Prescott } 1999 \\
\text { Johnson and Greene } 1991 \\
\text { Johnson and Greene } 1991 \\
\text { Johnson and Greene } 1991 \\
\text { Johnson and Greene } 1991 \\
\text { Johnson and Greene } 1991 \\
\text { Wei et al. } 1997 \\
\text { Wei et al. } 1997 \\
\text { Herrmann and Prescott } 2008\end{array}$ \\
\hline Red pine & Pinus resinosa Ait. & 0.0550 & Minnesota & Alban and Pastor 1993 \\
\hline Subalpine fir & Abies lasiocarpa (Hook.) Nutt. & $\begin{array}{l}0.0286 \\
0.0520\end{array}$ & $\begin{array}{l}\text { Alberta } \\
\text { Alberta }\end{array}$ & $\begin{array}{l}\text { Laiho and Prescott } 1999 \\
\text { Hermann and Prescott } 2008\end{array}$ \\
\hline White spruce & Picea glauca (Moench) Voss & $\begin{array}{l}0.0271 \\
0.0710 \\
0.0240\end{array}$ & $\begin{array}{l}\text { Alberta } \\
\text { Minnesota } \\
\text { Alberta }\end{array}$ & $\begin{array}{l}\text { Laiho and Prescott } 1999 \\
\text { Alban and Pastor } 1993 \\
\text { Hermann and Prescott } 2008\end{array}$ \\
\hline \multicolumn{5}{|l|}{ Hardwoods } \\
\hline Bigtooth aspen & Populus grandidentata Michx. & 0.0900 & Michigan & Gough et al. 2007 \\
\hline Eastern hemlock & Tsuga canadensis (L.) Carr & 0.0210 & Wisconsin, Michigan & Tyrrell and Crow 1994 \\
\hline Sugar maple & Acer saccharum Marsh. & 0.0750 & Wisconsin & Forrester et al. 2012 \\
\hline Trembling aspen & Populus tremuloides Michx. & 0.0800 & Minnesota & Alban and Pastor 1993 \\
\hline White ash & Fraxinus americana L. & 0.0750 & Wisconsin & Forrester et al. 2012 \\
\hline Hardwoods ${ }^{\mathrm{a}}$ & & 0.0365 & Ontario & Vanderwel et al. $2008^{\mathrm{b}}$ \\
\hline Hardwoods ${ }^{\mathrm{a}}$ & & 0.0330 & Ontario & Vanderwel et al. $2008^{c}$ \\
\hline
\end{tabular}

${ }^{a}$ Mostly sugar maple, with components of American beech, yellow birch, and eastern hemlock.

bUnmanaged stands; decay rate calculated from half-life time.

${ }^{\mathrm{c}}$ Managed stands; decay rate calculated from half-life time.

Estimates of carbon stored in live trees and standing dead trees are based on net merchantable volume. Estimates of carbon in down dead wood are based on relationships with live tree biomass that rely on factors such as mortality rates of live trees, ratios of down dead wood carbon to live tree carbon, and down dead wood decay factors. Forest floor and understory vegetation carbon pools are estimated based on stand age. Finally, soil carbon includes all organic carbon (excluding roots) in mineral soil to $1 \mathrm{~m}$ depth and is estimated using forest area and soil carbon density based on forest region and forest type. For additional detail on estimations of forest carbon pools in FORCARB-ON, see Chen et al. (2010).

Yield curves for regenerating forests were developed using equations from Penner et al. (2008). A tree species composition-based, area-weighted yield curve was assigned to each
FMU and used as an input for FORCARB-ON algorithms to calculate carbon stocks in regenerating forests in areas cleared of slash piles by burning. Carbon stocks in regenerating forests were converted into $\mathrm{CO}_{2}$ to estimate their annual and cumulative $\mathrm{CO}_{2}$ removals. Soil carbon stocks in areas covered with slash piles were assumed to be similar in both the noburn and baseline scenarios, and therefore were not included in $\mathrm{CO}_{2}$ removals in the baseline scenario.

\section{Sensitivity analysis}

Finally, we conducted a sensitivity analysis to assess the effect of the assumption that area covered with slash piles in the noburn scenario was taken out of the productive land base for the duration of the simulation period (i.e., until year 2100). For this analysis, cumulative area covered with unburned slash piles was estimated using the equation: 
(7)

$$
\mathrm{CA}(\mathrm{t})=\mathrm{CA}(\mathrm{t}-1)+\mathrm{A}(\mathrm{t})-\Sigma \mathrm{A}\left(\mathrm{t}_{\mathrm{i}} \mid \exp \left(-\mathrm{K}_{\mathrm{all}}\left(\mathrm{t}-\mathrm{t}_{\mathrm{i}}\right)\right)<\mathrm{K}_{\text {thres }}\right),
$$

Where:

CA is the cumulative area (ha) covered with unburned slash piles at the end of year t;

$\mathrm{K}_{\text {thres }}$ is the threshold value (dimensionless) below which the area previously covered with slash piles is considered to be cleared for regeneration due to natural decay; and,

$\mathrm{K}_{\text {all }}$ is the slash pile mass-weighted decay rate $\left(\right.$ year $\left.^{-1}\right)$, calculated as

(8) $\mathrm{K}_{\mathrm{all}}=\left(\Sigma \mathrm{B}_{\text {con }} \cdot \mathrm{K}_{\text {con }}+\Sigma \mathrm{B}_{\text {hwd }} \cdot \mathrm{K}_{\mathrm{hwd}}\right) /\left(\Sigma \mathrm{B}_{\text {con }}+\Sigma \mathrm{B}_{\text {hwd }}\right)$,

Where the summation $(\Sigma)$ is calculated over the entire simulation period (2016-2100). In essence, $\mathrm{K}_{\text {all }}$ is the average decay rate calculated using the FMU-specific breakdown of harvested volumes between softwoods and hardwoods. Equation (7) is based on the assumption that the height of decaying slash piles recedes uniformly in the horizontal plane. Once the ratio of the current mass of slash piles to their initial mass reaches the threshold value, $K_{\text {thres }}$ the area is assumed to regenerate naturally. The assumption of no-clearing of slash pile area due to decay used in the main analysis corresponded to a zero threshold value, $\mathrm{K}_{\text {thres }}=0$. For sensitivity analysis, $\mathrm{K}_{\text {thres }}$ was assigned values from 0 to 1 using increments of 0.1 . The area cleared of slash piles due to their decay in the no-burn scenario (i.e., the area for which the fraction of remaining slash pile mass was less than $\mathrm{K}_{\text {thres }}$ ) was assumed to regenerate following the same yield curves (and removal of $\mathrm{CO}_{2}$, respectively) as the area cleared by slash pile burning in the baseline scenario.

\section{Results}

Actual-to-planned harvest ratios $\left(\mathrm{F}_{\text {con }}\right.$ and $\mathrm{F}_{\mathrm{hwd}}$ ) were estimated for each FMU separately for conifers and hardwoods by dividing total actual harvest volume during 1990-2009 by total planned harvest volume during the same period. The actual-to-planned harvest volume ratios $\left(\mathrm{F}_{\text {con }}\right)$ for conifer species estimated for individual FMUs ranged from 0.2615 to 1.0419 , for an average ratio of 0.6577 . For hardwoods, the actual-to-planned harvest volume ratios $\left(\mathrm{F}_{\text {hwd }}\right)$ for individual FMUs ranged from 0.1213 to 0.6558 , for an average of 0.3847 .

The average annual maximum harvest projected for the AOU for 2016-2100 was 18.66 and 8.06 million $\mathrm{m}^{3}$ of softwood and hardwood, respectively. If scaled down to reflect historical harvesting levels of 1990-2009 using actual-toplanned ratios for individual FMUs, the average annual harvest projected for 2016-2100 was 11.09 and 3.28 million $\mathrm{m}^{3}$ of softwood and hardwood, respectively.

Estimated slash pile burning rates, $\mathrm{R}$, for individual FMUs are shown in Fig. 1. Based on the annual reports during 2008-2013, slash pile burning was (either periodically or regularly) conducted in 24 FMUs; during this period no slash pile burning was conducted in 17 FMUs. Estimated FMUspecific annual slash pile burning rates ranged from 0.0167 to 0.6829 . The average annual slash pile burning rate for the $\mathrm{AOU}$ was 0.2422 . The latter average rate was calculated using rates for individual FMUs weighted by historical harvest volume during 2010 to 2014. Estimated slash pile combustion rates for individual FMUs ranged from 0.63 to 0.95 . The average combustion rate for the AOU calculated using only FMUs where slash pile burning occurred during 2008 to 2013 was
0.88 . The latter value is in keeping with estimates reported in the literature. For example, Finkral et al. (2012) estimated the fraction of slash piles consumed by burning to be between 92\% and 94\%; Hardy (1996) stated that "the percentage of wood mass consumed when piles are burned typically ranges between 75 and 95 percent" and recommended using $88 \%$ as an average estimate.

A comparison of cumulative GHG emissions in the noburn 2016-2050 scenario versus the baseline scenario is shown in Fig. 2; avoided emissions are shown as negative values while positive values correspond to emissions and foregone removals in the no-burn scenario. Avoided emissions from suspending slash pile burning (what would have burned in the baseline scenario) kept accumulating until slash pile burning resumes in 2051, after which they remained constant (short-dashed line in Fig. 2). Emissions from decay of unburned slash in the no-burn scenario increased steadily from 2016 to 2100 (long-dashed line in Fig. 2), so did the removals of $\mathrm{CO}_{2}$ by forest that would be regenerating in areas cleared by slash pile burning in the baseline scenario, which are foregone in the no-burn scenario (dashed-dotted line in Fig. 2). Consequently, the net difference in GHG emissions between the no-burn and baseline scenario (solid line in Fig. 3) increased from 2016 to 2050 , when it reached the cumulative value of $-23.20 \mathrm{Mt}$ $\mathrm{CO}_{2}$ eq (millions of tonnes of $\mathrm{CO}_{2}$ equivalent). Resumption of slash pile burning and continued accumulation of emissions from decay of unburned slash and foregone removal of $\mathrm{CO}_{2}$ led to a gradual reduction in the cumulative net GHG emissions, reaching $-4.47 \mathrm{Mt} \mathrm{CO}_{2}$ eq by 2100 .

The cumulative net difference in GHG emissions between the no-burn and baseline scenarios for all four periods of suspended slash pile burning is shown in Fig. 3 (the long-dash line in this figure is the solid line in Fig. 2). As expected, the longer period without slash pile burning results in higher cumulative avoided emissions by 2100 that reached the values

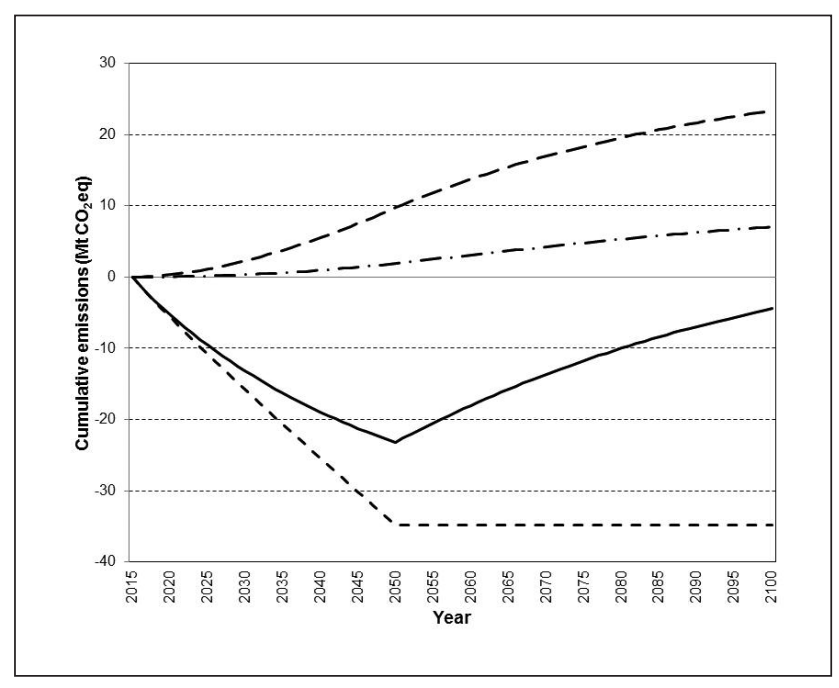

Fig. 2. Cumulative greenhouse gas emissions and removals in the no-burn 2016-2050 scenario: emissions avoided by suspending slash pile burning (short dash), emissions from decay of unburned slash piles (long dash), foregone removals by regenerating forest (long dash-dot), and cumulative net difference in emissions between the no-burn and baseline scenarios (solid line). Negative numbers indicate avoided emissions (i.e., removals) 


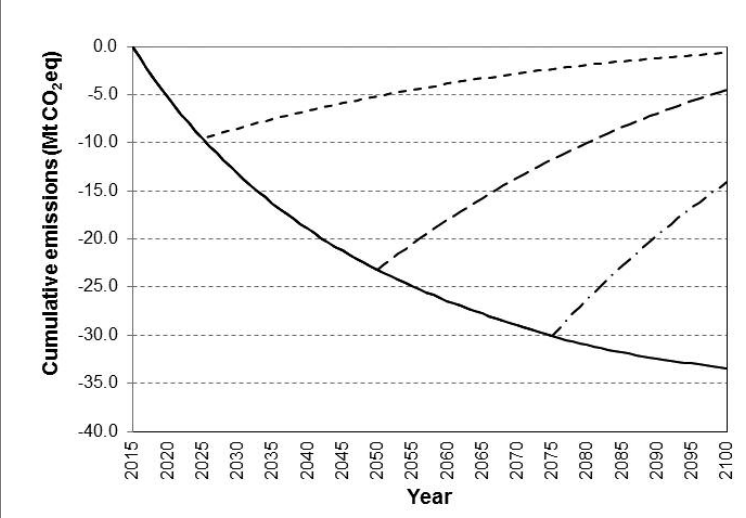

Fig. 3. Cumulative avoided greenhouse gas emissions in the noburn scenario from suspending slash pile burning for 2016-2025 (short dash), 2016-2050 (long dash), 2016-2075 (long dash-dot), and 2016-2100 (solid line).

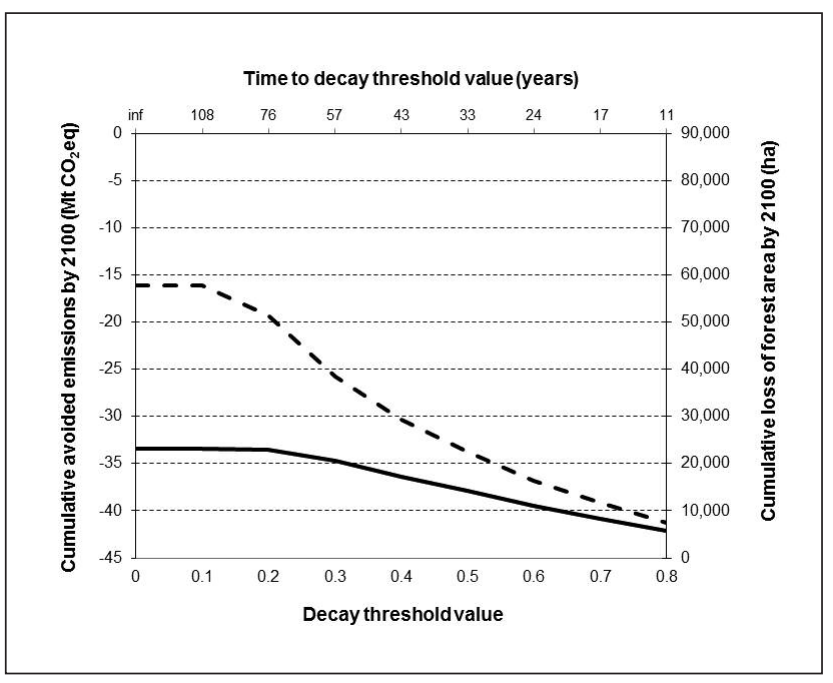

Fig. 4. Effect of decay threshold value ( $K_{\text {thres }}$ in Eq. 7) on avoided greenhouse gas emissions (solid line) and area unavailable for forest regeneration (dashed line) accumulated by 2100 in the noburn 2016-2100 scenario.

of $-0.66,-4.47,-14.09$, and $-33.43 \mathrm{Mt} \mathrm{CO}_{2}$ eq for slash pile burning suspended during 2016-2025, 2016-2050, 2016-2075, and 2016-2100, respectively. Conversely, longer periods of suspended slash pile burning result in larger cumulative areas covered with slash piles (and thus lost to regeneration) that by 2100 reach values of 7154, 23968,40804 , and 57830 ha for the four periods of suspended slash pile burning, respectively.

The large areas of non-regenerating forest in the no-burn scenario result from the assumption that all area covered with unburned slash piles remains unavailable for forest regeneration through 2100. We evaluated the effect of this assumption on avoided emissions from slash pile burning. The effect of decomposition threshold, $\mathrm{K}_{\text {thres }}$ (Eq. 7), on cumulative avoided emissions and area covered with slash piles in the noburn 2016-2100 scenario is shown in Fig. 4. Threshold values above 0.2 substantially increased the area regenerated. However, the effect on cumulative avoided emissions is slower, due to the time required for regenerating forest to sequester appreciable amounts of carbon.

\section{Discussion}

Suspending the current practice of disposing of slash piles by burning without energy recovery may substantially reduce GHG emissions; suspending slash pile burning until 2100 would yield over $33 \mathrm{Mt} \mathrm{CO}_{2}$ eq in avoided emissions. The negative effect of suspending slash pile burning is the increased area occupied by unburned slash. Assuming none of the logging slash in areas covered by piles decomposed enough to allow trees to regenerate, by 2100 the loss of productive forest land by suspending slash pile burning from 2016 to 2100 would reach almost 58000 ha, or about $0.2 \%$ of total productive forest area (Watkins 2011). This negative effect would be reduced by applying harvesting methods that disperse rather than pile slash, or chipping and re-distributing it on the harvested area, or removing it for biomass fuel production (SFI 2009). In any case, additional treatments to reduce slash piles would result in GHG emissions from burning fossil fuels that must also be accounted for in determining the net GHG emission reduction benefit of suspending slash pile burning.

Area lost to unburned slash piles would eventually be cleared due to decomposition and thus become available for forest regeneration. This in turn would result in $\mathrm{CO}_{2}$ removals from the atmosphere by regenerating forest and further reduce GHG emissions in the no-burn scenario compared to the baseline scenario. For example, the sensitivity analysis showed that if in the no-burn 2016-2100 scenario, we assumed the area covered with slash piles to be available for forest regeneration in 50 years from when slash piles are created, then by 2100 the cumulative area covered with slash piles would decrease by about 20000 ha and the cumulative amount of avoided GHG emissions would increase by about $2 \mathrm{Mt} \mathrm{CO}_{2}$ eq.

A valid question is whether the area covered with unburned slash piles should be counted as a loss of productive forest area. Logically, the presence of slash piles reduces area available for regeneration and thus affects stem density in regenerating forest. For example, an average slash pile in northwestern Ontario (as reported by Gautam et al. 2012) covers over $100 \mathrm{~m}^{2}$ and thus constitutes a physical barrier to either natural regeneration or planting. However, surrounding regenerating trees may benefit from increased availability of nutrients, light, and water due to the artificial gap created by a slash pile, and their growth may compensate for the reduced initial stem density, perhaps eventually resulting in no difference in total biomass between stands with and without unburned slash piles. Based on the latter considerations, Hall (2005) concluded that negative effect of unburned slash piles on the establishment of new stands on Vancouver Island was not a concern. But will such compensating effect really happen and how long might it take for the difference to become negligible? As appears to be the case for all aspects of slash pile burning, empirical observations are scarce. A rare piece of evidence comes from MacIsaac et al. (2006) who reported that "gaps" in post-harvest regeneration of trembling aspen (Populus tremuloides) created by slash piles were still easily identifiable 14 years after harvest, resulting in lower 
stem density in stands with unburned slash piles. In light of the inconclusive evidence on the effect of unburned slash piles on the growth of post-harvest stands and the lack of defensible estimates of the time required for decomposition of piles to clear the area covered with slash, we used a conservative approach and assumed the area covered with slash piles would not contribute to the productive forest area until 2100 (i.e., for the duration of simulation period). Consequently, the results of this study may be viewed as a lower limit estimate of avoided GHG emissions and upper level estimate of the area available for forest regeneration in the no-burn scenario.

The results of this study depend heavily on the estimates of rates of processes included in the analysis (e.g., slash pile production rate, slash pile decay rate, slash pile burning rate). Some of these estimates can be verified indirectly by comparing them with estimates published elsewhere, while for others relevant literature is non-existent. For example, estimates of slash pile production rates appear to be within the range of those reported in the literature. In a Canada-wide study, Dymond et al. (2010) estimated the ratio of harvesting residue available for bioenergy to total harvest volume at $0.2175 \mathrm{odt} \cdot \mathrm{m}^{-3}$ (all species combined). The latter value does not include a net-down factor, i.e., the fraction of slash left scattered on harvested sites for ecological purposes and due to harvesting methods; with the 50\% net-down factor recommended by Dymond et al. (2010), the ratio is reduced to $0.1088 \mathrm{odt} \cdot \mathrm{m}^{-3}$. Other researchers reported ratios of 0.1748 odt $\cdot \mathrm{m}^{-3}$ (Froese et al. 2010; Michigan, Minnesota, and Wisconsin), 0.1075-0.1774 odt.m ${ }^{-3}$ (Mabee et al. 2006; all Canada), 0.3918 odt $\cdot \mathrm{m}^{-3}$ (Wetzel et al. 2006; all Canada), and 0.4581 odt $\cdot \mathrm{m}^{-3}$ (Wood and Layzell 2003; all Canada). As noted by Dymond et al. (2010), the variation among these values is created by annual variability in harvesting rates, assumptions about the proportion of residues left on-site, and the study area; higher estimates typically do not include a netdown for sustainability. For a discussion on variability in estimates of harvesting residue in Canada, see also Parzei et al. (2014).

The slash pile burning rate is the most difficult estimate to verify since studies on GHG emissions generated by slash pile burning are extremely rare. The only Canadian study we are aware of that provides estimates of GHG emissions from slash pile burning was published by Smyth et al. (2014). They used an expert opinion-based constant slash pile burning rate of 0.05-0.10 applied to all annual harvest area in Ontario, equivalent to an assumption that all unmerchantable aboveground parts of trees were piled and burned on 5 to $10 \%$ of total harvested area each year. The slash pile burning rates used in our study were FMU-specific, with the average slash pile burning rate for the $\mathrm{AOU}(0.2422)$ being considerably higher than that used by Smyth et al. (2014). Although our estimates were not based on expert opinion but rather on annual reports on completed forested operations, analysis of annual reports revealed several difficulties affecting estimates of slash pile burning rate. First, in many FMUs, slash piles are not burned annually but can be delayed for a year or more, either to accumulate more slash piles or due to logistical difficulties with conducting the burn. Therefore, average annual slash pile burning rates may be underestimated for some FMUs due to our short sampling period (2008-2013). Second, some annual reports refer to slash pile burning operations but do not provide quantitative estimates of the cleared area; in such cases we assumed the burning to be conducted at either FMU-specific or regional average annual slash pile burning rates. And third, in some cases it is unclear whether the area reported as cleared by slash pile burning was based on ocular estimates or direct measurements.

The need for better data on slash pile burning rates is clear. In the absence of such data, the annual reports used in this study provided the best available information for Ontario. Also notable is that the estimates of GHG emissions produced in this study are linearly dependent on the slash pile burning rate estimates; changes in the rate would proportionally increase or reduce the net difference in GHG emissions between the no-burn and baseline scenarios.

Several factors that potentially affect the estimated net difference in GHG emissions were not included in this study because current knowledge of the magnitude or even the sign of these effects is inadequate. First, future slash pile burning projected in the baseline scenario was assumed to occur at the historically estimated rate. In light of the growing interest in using forest bioenergy, some of that slash might be collected for use as a biofuel for energy generation, thus reducing available "burnable" slash. As demonstrated by several studies, using slash (that would otherwise be burned) for energy generation to replace fossil fuel instantaneously reduces GHG emissions (Stephenson and MacKay 2014, Ter-Mikaelian et al. 2015b). Second, in the no-burn scenario the bottom portion of slash piles may be buried in the soil or moss layer, which could change the decay rate relative to the aboveground portion of slash piles. Third, slash pile burning may affect the productivity of post-burn sites, specifically nutrient availability and growth of understory vegetation competing with trees for resources such as light. For example, Thorpe and Timmer (2005) reported increased growth of jack pine (Pinus banksiana) seedlings three years after planting in slash-pile-burn plots compared to control plots in northeastern Ontario. On the other hand, Rhoades and Fornwalt (2015) reported that slash pile burning created poorly stocked openings in naturally regenerating lodgepole pine (Pinus contorta var. latifolia Engelm.) in Colorado that persisted for up to 50 years after burning. Jönsson and Nihlgård (2004) observed no difference in herb cover one year after slash pile burning in Norway spruce clearcuts in southern Sweden, but indicated increased risk of nutrient imbalance in the next forest generation. Overall, the effects on productivity appear to be better studied for broad-scale slash burning, i.e., prescribed burning (e.g., see Lindeburgh 1990 and Carter and Foster 2004), while studies specific to slash pile burning are too rare to yield conclusive evidence of the effects. Therefore, our estimates of carbon removals by regeneration in areas cleared by slash pile burning do not include effects of slash pile burning on site productivity.

In this study we considered only GHG emissions from slash pile combustion and decay and $\mathrm{CO}_{2}$ removals by regenerating forest. GHG emissions associated with carrying out slash pile burning (e.g., fossil fuel emissions from transporting crews to and from slash pile burning sites) were not included. We also did not consider potential secondary consequences, such as GHG emissions from wildfires, the incidence of which might be affected by suspending slash pile burning; slash pile burning is a fuel-reduction treatment that 
can temporarily reduce forest fire hazard (Campbell et al. 2012); slash piles can affect the risk of fire spread (e.g., Williams 1955) or facilitate surface fires spreading to crowns by providing so-called ladder fuels (Agee and Skinner 2005). However, ascertaining the increased fire risk posed by unburned slash piles would require a detection of statistically significant difference in the long-term average characteristics of fire regimes between similar forest landscapes with contrasting treatment of slash piles (burn vs. no burn). In the absence of such tests, attributing a fraction of GHG emissions from wildfires to unburned slash piles would be impossible, even if such effects were within the scope of our study.

In addition to GHG emissions, slash pile burning may have other effects on social and biological aspects of forests. Some effects that could be important if slash pile burning were suspended include increased soil organic carbon, decreased soil permeability due to creation of a discreet and continuous water-repellent layer parallel to the soil surface, increased soil bulk density, and changes in the amount and chemical form of nitrogen and phosphorus. Such effects are likely to be contained within the top $(20-30 \mathrm{~cm})$ soil layer and last only a few years after fire (Certini 2005). Fire is also likely to reduce the total biomass of soil microorganisms for up to a decade and reduce both the total mass and number of species of soil dwelling invertebrates for up to a year (Certini 2005). Burning slash piles may also create forest gaps, increasing susceptibility to invasion by exotic plants (Korb et al. 2004). Finally, slash pile burning may affect abiotic aspects of forests, for example by improving their aesthetic value since one of the most significant predictors of negative perception of scenic beauty of forests is residual woody debris (Ryan 2005).

The estimates produced in this study provide a preliminary indication of the potential mitigation benefit from suspending slash pile burning in Ontario relative to potential initiatives in other sectors. Proposed initiatives to reduce GHG emissions in other major sectors of Ontario's economy could result in -4.6 (transportation), -0.8 (industry), -2.3 (buildings), and -1.8 $\mathrm{Mt}$ (agriculture and waste sectors reductions) in $\mathrm{CO}_{2}$ eq emissions by 2020 (OMOECC 2014). For comparison, suspension of slash pile burning within the Area of Undertaking in all four considered scenarios is estimated to result in $-5.3 \mathrm{Mt} \mathrm{CO}_{2}$ eq in cumulative reduced emissions by 2020, about -1 Mt $\mathrm{CO}_{2}$ eq annually. Suspending slash pile burning until 2050 and beyond would result in cumulative GHG emissions reduction of $-23.2 \mathrm{Mt} \mathrm{CO}_{2} \mathrm{eq}$, or $-0.66 \mathrm{Mt}$ $\mathrm{CO}_{2}$ eq annually. While the latter number constitutes less than $0.5 \%$ of the total GHG emission reduction of $-141 \mathrm{Mt} \mathrm{CO}_{2} \mathrm{eq}$ required to meet Ontario's 2050 emissions reduction target (OMOECC 2014), suspension of slash pile burning does not require an additional investment or new tools. Ease of implementation could make it an attractive emission reduction option, although the final decision on suspending slash pile burning must be based not only on its GHG emission reduction potential but on a comprehensive assessment of all its effects on forests.

Finally, while simulations of cumulative GHG emissions and removals beyond 2100 were not attempted, data in Fig. 3 suggests that the net cumulative difference in GHG emissions between the no-burn and baseline scenarios may converge to an asymptote. Nonetheless, it would be erroneous to dismiss the potential contribution of suspending slash pile burning to climate change mitigation on the grounds that it may merely delay the emissions because carbon contained in slash piles will be eventually transferred to the atmosphere via slash decay. As noted by Hall (2005), suspending slash pile burning results in permanent climate change mitigation effect since some of the emissions from burning occurs in the form of non- $\mathrm{CO}_{2}$ gases that have a higher global warming potential (and thus larger effect on climate) than $\mathrm{CO}_{2}$. More important is the fact that, as stated by Dehue (2013), society will likely require the use of all available options to mitigate climate change, whether they provide short- or long-term GHG reduction benefits.

\section{Acknowledgements}

We thank Nick Baggs, Steve Banducci, Glen Foley, Jenny Gleeson, and Ngaire Roubal for helpful comments and Lisa Buse (all with the Ontario Ministry of Natural Resources and Forestry) for editing an earlier version of this manuscript. We also thank three anonymous reviewers from the journal for valuable suggestions for improving the manuscript.

\section{References}

Agee, J.K. and C.N. Skinner. 2005. Basic principles of forest fuel reduction treatments. Forest Ecol. Manag. 211: 83-96.

Alban, D.H. and J. Pastor. 1993. Decomposition of aspen, spruce, and pine boles on two sites in Minnesota. Can. J. Forest Res. 23: 1744-1749.

Bond-Lamberty, B. and S.T. Gower. 2008. Decomposition and fragmentation of coarse woody debris: Re-visiting a boreal black spruce chronosequence. Ecosystems 11: 831-840.

Boulanger, Y. and L. Sirois. 2006. Postfire dynamics of black spruce coarse woody debris in northern boreal forest of Quebec. Can. J. Forest Res. 36: 1770-1780.

Campbell, J.L., M.E. Harmon and S.R. Mitchell. 2012. Can fuelreduction treatments really increase forest carbon storage in the western US by reducing future fire emissions? Front. Ecol. Environ. 10: 83-90.

Carter, M.C. and C.D. Foster. 2004. Prescribed burning and productivity in southern pine forests: A review. Forest Ecol. Manag. 191: 93-109.

Certini, G. 2005. Effects of fire on properties of forest soils: A review. Oecologia 143: 1-10.

Chen, J., S.J. Colombo, M.T. Ter-Mikaelian and L.S. Heath. 2010. Carbon budget of Ontario's managed forests and harvested wood products, 2001-2100. Forest Ecol. Manag. 259: 1385-1398.

Chen, J., S.J. Colombo, M.T. Ter-Mikaelian and L.S. Heath. 2014. Carbon profile of the managed forest sector in Canada in the 20th century: Sink or source? Environ. Sci. Tech. 48: 9859-9866.

Dehue, B. 2013. Implications of a 'carbon debt' on bioenergy's potential to mitigate climate change. Biofuel. Bioprod. Bior. 7: 228-234.

Dymond, C.C., B.D. Titus, G. Stinson and W.A. Kurz. 2010. Future quantities and spatial distribution of harvesting residue and dead wood from natural disturbances in Canada. Forest Ecol. Manag. 260:181-192.

Environment Canada. 2015. National Inventory Report on Greenhouse Gas Sources and Sinks in Canada 1990-2013. Environment Canada, Gatineau, Quebec. Available at <https://unfccc.int/ national_reports/annex_i_ghg_inventories/national_inventories_su bmissions/items/8812.php> [accessed 2 February 2016].

Finkral, A.J., A.M. Evans, C.D. Sorensen and D.L.R. Affleck. 2012. Estimating consumption and remaining carbon in burned slash piles. Can. J. Forest. Res. 42: 1744-1749.

Forbes, M.S., R.J. Raison and J.O. Skjemstad. 2006. Formation, transformation and transport of black carbon (charcoal) in terrestrial and aquatic ecosystems. Sci. Total Environ. 370: 190-206. 
Forrester, J.A., D.J. Mladenoff, S.T. Gower and J.L. Stoffel. 2012. Interactions of temperature and moisture with respiration from coarse woody debris in experimental forest canopy gaps. Forest Ecol. Manag. 265: 124-132.

Froese, R.E., D.R. Shonnard, C.A. Miller, K.P. Koers and D.M. Johnson. 2010. An evaluation of greenhouse gas mitigation options for coal-fired power plants in the US Great Lakes States. Biomass Bioenerg. 34: 251-262.

Gautam, S., R. Pulkki, C. Shahi and M. Leitch. 2012. Fuel quality changes in full tree logging residue during storage in roadside slash piles in Northwestern Ontario. Biomass Bioenerg. 42: 43-50.

Gough, C.M., C.S. Vogel, C. Kazanski, L. Nagel, C.E. Flower and P.S. Curtis. 2007. Coarse woody debris and the carbon balance of a north temperate forest. Forest Ecol. Manag. 244: 60-67.

Hall, A.W. 2005. The greenhouse gas impacts of burning postharvest debris piles on Vancouver Island, BC. Ms. Thesis, Simon Fraser University. Available at <http://summit.sfu.ca/item/11261> [accessed 27 May 2016].

Hardy, C.C. 1996. Guidelines for estimating volume, biomass, and smoke production for piled slash. U.S. Department of Agriculture Forest Service, Pacific Northwest Research Station, Portland, OR. General Technical Report PNW-GTR-364. 17 p.

Herrmann, S. and C.E. Prescott. 2008. Mass loss and nutrient dynamics of coarse woody debris in three Rocky Mountain coniferous forests: 21 year results. Can. J. Forest Res. 38: 125-132.

IPCC. 2003. [Intergovernmental Panel on Climate Change]. Good Practice Guidance for Land Use, Land-Use Change and Forestry. Intergovernmental Panel on Climate Change National Greenhouse Gas Inventories Programme. Available online at $<$ www.ipcc-nggip.iges.or.jp/public/gpglulucf/gpglulucf.htm > [accessed 2 February 2016].

IPCC. 2007. [Intergovernmental Panel on Climate Change]. Climate Change 2007: The Physical Science Basis. Summary for Policymakers. Available at <https://www.ipcc.ch/publications_and_data/ publications_and_data_reports.shtml $>$ [accessed 2 February 2016]. IPCC. 2013. [Intergovernmental Panel on Climate Change]. Myhre, G., D. Shindell, F.-M. Bréon, W. Collins, J. Fuglestvedt, J. Huang, D. Koch, J.-F. Lamarque, D. Lee, B. Mendoza, T. Nakajima, A. Robock, G. Stephens, T. Takemura and H. Zhang: Anthropogenic and Natural Radiative Forcing. In: Climate Change 2013: The Physical Science Basis. Contribution of Working Group I to the Fifth Assessment Report of the Intergovernmental Panel on Climate Change [Stocker, T.F., D. Qin, G.-K. Plattner, M. Tignor, S.K. Allen, J. Boschung, A. Nauels, Y. Xia, V. Bex and P.M. Midgley (eds.)]. Cambridge University Press, Cambridge, United Kingdom and New York, NY, USA. Available at <https://www.ipcc.ch/report/ar5/> [accessed 2 February 2016].

Johnson, E.A. and D.F. Greene. 1991. A method for studying dead bole dynamics in Pinus contorta var. latifolia - Picea engelmannii forests. J. Veg. Sci. 2: 523-530.

Jönsson, A.M. and B. Nihlgård. 2004. Slash pile burning at a Norway spruce clear-cut in southern Sweden. Water Air Soil Poll. 158: 127-135.

Korb, J.E., N.C. Johnson and W.W. Covington. 2004. Slash pile burning effects on soil biotic and chemical properties and plant establishment: Recommendations for amelioration. Restor. Ecol. 12: $52-62$.

Laiho, R. and C.E. Prescott. 1999. The contribution of coarse woody debris to carbon, nitrogen, and phosphorous cycles in three Rocky Mountain coniferous forests. Can. J. Forest. Res. 29: 1592-1603.

Laiho, R. and C.E. Prescott. 2004. Decay and nutrient dynamics of coarse woody debris in northern coniferous forests: A synthesis. Can. J. Forest Res. 34: 763-777.

Lindeburgh, S.B. 1990. Effects of prescribed fire on site productivity: A literature review. BC Ministry of Forests, Victoria, British Columbia, Canada. 20 p. Available at <https://www.for.gov.bc.ca/ hfd/pubs/docs/mr/Lmr/Lmr066.pdf> [accessed 2 February 2016].
Mabee, W., E.D.G. Fraser, P.N. McFarlane and J.N. Saddler. 2006. Canadian biomass reserves for biorefining. Appl. Biochem. Biotec. 129: 22-40.

MacIsaac, D.A., P.G. Comeau and S.E. MacDonald. 2006. Dynamics of regeneration gaps following harvest of aspen stands. Can. J. Forest Res. 36: 1818-1833.

OMOECC. 2014. [Ontario Ministry of the Environment and Climate Change]. Ontario's Climate Change Update 2014. Ontario Ministry of the Environment and Climate Change. Available from $<$ http://www.ontario.ca/document/ontarios-climate-changeupdate-2014> [accessed 2 February 2016].

OMNR. 2009. [Ontario Ministry of Natural Resources]. Forest Information Manual. Forest Resources Inventory Technical Specifications 2009. Ontario Ministry of Natural Resources. Available at $<$ https://www.ontario.ca/document/forest-resources-inventorytechnical-specifications $>$ [accessed 2 February 2016].

OMNR. 2010. [Ontario Ministry of Natural Resources]. Forest Management Guide for Conserving Biodiversity at the Stand and Site Scales. Ontario Ministry of Natural Resources. Queen's Printer for Ontario. $211 \mathrm{p}$.

OMNRF. 2015. [Ontario Ministry of Natural Resources and Forestry]. Analysis of Regional Wood Supply 2015 v1 DRAFT; Appendix 1 - Provincial Wood Supply Strategy. Ontario Ministry of Natural Resources and Forestry, Forest Industry Division, Sault Ste. Marie, Ontario.

Parzei, S., S. Krigstin, K. Hayashi and S. Wetzel. 2014. Forest harvest residues available in Eastern Canada-a critical review of estimations. Forest. Chron. 90:778-784.

Penner, M., M. Woods, J. Parton and A. Stinson. 2008. Validation of empirical yield curves for natural-origin stands in boreal Ontario. Forest. Chron. 84: 704-717.

Preston, C.M. and M.W.I. Schmidt. 2006. Black (pyrogenic) carbon: A synthesis of current knowledge and uncertainties with special consideration of boreal regions. Biogeosciences 3: 397-420.

Rhoades, C.C. and P.J. Fornwalt. 2015. Pile burning creates a fiftyyear legacy of openings in regenerating lodgepole pine forests in Colorado. Forest Ecol. Manag. 336: 203-209.

Ryan, R. L. 2005. Social science to improve fuels management: A synthesis of research on aesthetics and fuels management. General Technical Report NC-261. St. Paul, MN: U.S.D.A. Forest Service, North Central Research Station. 58 p.

SFI. 2009. [Sustainable Forestry Initiative]. A Guide to Best Management Practices for Forest Operations in Northern Ontario, Version 2.0. Central Canada Sustainable Forestry Initiative. Available at <http://www.sficentralcanada.org/Downloads.html> [accessed 2 February 2016].

Smyth, C.E., G. Stinson, E. Neilson, T.C. Lemprière, M. Hafer, G.J. Rampley and W.A. Kurz. 2014. Quantifying the biophysical climate change mitigation potential of Canada's forest sector. Biogeosciences 11: 3515-3529.

Statutes of Ontario. 1995. Crown Forest Sustainability Act, revised. R.S.O. 1998. Chapter 25 and Ontario Regulation 167/95.

Stephenson, A.L. and D.J.C. MacKay. 2014. Scenarios for assessing the greenhouse gas impacts and energy input requirements of using North American woody biomass for electricity generation in the UK. Report URN 14D/243, Department of Energy and Climate Change, UK. Available at <https://www.gov.uk/government/publications/life-cycle-impacts-of-biomass-electricity-in-2020> [accessed February 2, 2016]

Ter-Mikaelian, M., S. Colombo and J. Chen. 2013. Effects of harvesting on spatial and temporal diversity of carbon stocks in a boreal forest landscape. Ecol. Evol. 3(11): 3738-3750.

Ter-Mikaelian, M.T., S.J. Colombo, D. Lovekin, J. McKechnie, R. Reynolds, B. Titus, E. Laurin, A.-M. Chapman, J. Chen and H.L. MacLean. 2015a. Carbon debt repayment or carbon sequestration parity? Lessons from a forest bioenergy case study in Ontario, Canada. Global Change Biol. Bioen. 7: 704-716. 
Ter-Mikaelian, M., S. Colombo and J. Chen. 2015b. The burning question: Does forest bioenergy reduce carbon emissions? A review of common misconceptions about forest carbon accounting. J. Forest. 113: 57-68.

Thorpe, H.C. and V.R. Timmer. 2005. Early growth and nutrient dynamics of planted Pinus banksiana seedlings after slashpile burning on a boreal forest site. Can. J. Soil Sci. 85: 173-180.

Tyrrell, L.E. and T.R. Crow. 1994. Dynamics of dead wood in oldgrowth hemlock-hardwood forests of northern Wisconsin and northern Michigan. Can. J. Forest Res. 24: 1672-1683.

Vanderwel, M.C., H.C. Thorpe, J.L. Shuter, J.P. Caspersen and S.C. Thomas. 2008. Contrasting downed woody debris dynamics in managed and unmanaged northern hardwood stands. Can. J. Forest Res. 38: 2850-2861.

Wang, C., B. Bond-Lamberty and S.T. Gower. 2002. Environmental controls on carbon dioxide flux from black spruce coarse woody debris. Oecologia 132: 374-381.

Watkins, L. 2011. The forest resources of Ontario 2011. Ontario Ministry of Natural Resources, Sault Ste. Marie Ontario, Forest Eval- uation and Standards Section, Forests Branch. 307 p. Available at <https://www.ontario.ca/document/forest-resources-ontario-2011> [accessed 2 February 2016].

Wei, X., J.P. Kimmins, K. Peel and O. Steen. 1993. Mass and nutrients in woody debris in harvested and wildfire-killed lodgepole pine forests in the central interior of British Columbia. Can. J. Forest Res. 27: 148-155.

Wetzel, S., L. Duchesne and M. LaPorte. 2006. Bioproducts from Canadian Forests: New Partnerships in the Bioeconomy. Springer, Dordrecht, the Netherlands.

Williams, D.E. 1955. Fire hazard resulting from jack pine slash. Technical Note 22, Forest Research Division, Department of Northern Affairs and National Resources, Canada. Available at < http://www.cfs.nrcan.gc.ca/bookstore_pdfs/30493.pdf> [accessed 20 May 2016].

Wood, S.A. and D.B. Layzell. 2003. A Canadian biomass inventory: Feedstocks for a bio-based economy. BIOCAP Canada Foundation Report. 42 p. 